\title{
Female Crime in the New Millennium: a review of literature between 2001 and 2021
}

\author{
Bruno Brandão Pereira Machado ${ }^{1 *}$; Giselle Katerine Cristovão da Silva ${ }^{2}$; Kelyane Maria de Souza ${ }^{3}$; \\ Maria Eduarda Camelo de Brito ${ }^{4}$; Romilda Lopes de Souza ${ }^{5}$; Pierre Teodosio Felix ${ }^{6}$
}

1-5 Psychology Students at University Center of Vitória de Santo Antão (UNIVISA), Vitória de Santo Antão, Pernambuco, Brazil 6 Professor of Psychology Course at University Center of Vitória de Santo Antão (UNIVISA), Vitória de Santo Antão, Pernambuco, Brazil

E-mail adresses: bruno.b.machado87@gmail.com (Bruno Brandão Pereira Machado), Gi.katerine24@gmail.com (Giselle Katerine), kelyanesouza238@gmail.com (Kelyane Maria de Souza), mariaeduarda1234om@gmail.com (Maria Eduarda Camelo de Brito), lromilda404@gmail.com (Romilda Lopes de Souza),pierrefelix@univisa.edu.br (Pierre Teodosio Felix)

${ }^{*}$ Corresponding author

\section{To cite this article:}

Machado, B.B.P.; Silva, G.K.C.; Souza, K.M.; Brito, M.E.C.; Souza, R.L.; Felix, P.T. Female Crime in the New Millennium: a review of literature between 2001 and 2021. International Journal of Sciences. Vol. 2, No. 3, 2021, pp.101-104. ISSN $2763-5392$.

Received: 10 25, 2021; Accepted: 10 25, 2021; Published: 11 03, 2021

\begin{abstract}
Crime has been an environment dominated - for the most part - by the male figure. The idea of a woman capable of committing crimes is something that shocks society, accustomed to seeing docility and kindness in the female figure. The concept of infirmita sexus (fragile sex, in Latin) puts the woman in a position of inferiority in relation to the man and makes justice more lenient with them. With a growing number of women in crime, there is a need for an honest debate about their real participation in this environment. This article aims to carry out bibliographic research, based on scholars who have relevant knowledge on the subject, as well as linked files in digital media. And the intention is to analyze the subject in a qualitative and theoretical way in order to break the prejudice and the almost mystical vision of the docile and peaceful woman.
\end{abstract}

Keywords: Women. Crime. Women in crime. Criminal Women.

\section{Introduction}

In the preface to his book "The Delinquent Woman", published in 1893, the father of criminal anthropology, Cesare Lombroso, writes - along with Guglielmo Ferrero - that: "the woman is intellectually and physically like a man who had his development interrupted". (p. 9). The authors go on to say that the male is "an improved and more variable female" (p. 20). This inferiority would put the woman in a more docile and gentle position than the man, less conducive to delinquency (Lombroso and Ferrero, 2017).

For a long time, it was believed that female crime was associated with male crime data and, therefore, there was no interest in researching this reality in a specific way. The increase in female protagonist in crime is largely due to the increase in their insertion and presence in the various segments of society - previously mostly male (Salmasso, 2004).

Because of the lower number of crimes committed by women, it becomes an unattractive topic for academic production. Thus, studies on the subject are rare (Magno, 2019). In this context, the article presented here seeks to show how the criminal woman is still seen with prejudiced content in the motivation of her crimes.

\section{Methodology}

This is a study with data collection based on bibliographic data collection. For this survey, articles were retrieved from the Scientific Electronic Library Online (SciELO) and Google Scholar. The inclusion criteria determined for the articles were: texts available in full, articles in Portuguese from 2001 to 2021; dealing with criminal activities with female protagonist. Reference books by national authors addressing the theme were also used. The Delinquent Woman (1893), the work of Lombroso, who first addressed the subject, was also consulted. 


\section{Results and Discussion}

Historically, women have always been seen as fragile and docile. Because of this, their role in crime has always been seen related to man. They are seen as inferior and incapable of committing crimes, only doing so by male influence, or because of passion (Faria, 2010).

The fact that women were prevented from acting in certain areas of society has limited - for a long time - their criminal potential. This may explain the disparity between the number of male and female prisoners. However, it is not the only explanation. The fact is that justice is more lenient with criminal women. Studies conducted in the United States show that women are less likely to be charged or convicted for their crimes and, when convicted, are more likely to face sentences other than incarceration. When they are sentenced to prison, female criminals receive, on average, $63 \%$ less time of sentence than men arrested for the same crimes. If women are less accused, convicted and - when imprisoned spend less time in prison, their prison population is expected to be smaller than that of the male one (Starr, 2012).

There has been a considerable increase in the number of women imprisoned worldwide. An increase of $53 \%$ of the female prison population in the world is evidenced, and in Brazil, this increase has been $656 \%$ since 2000 . Prison remains a mostly male environment, but the data are alarming and deserve attention. Women prisoners follow the same profile as male prisoners: social and economic vulnerability. They are mostly black and low scholarlily. In addition, $50 \%$ of inmates are in the age group from 18 to 29 years (Germano et al, 2018).

According to Da Paixão, et al: "The loving involvement of women with men linked to drug trafficking and linked to crime is one of the important facts for female criminal behavior." (p. 8). According to the authors, many women relate to men linked to drug trafficking because they show strength and power, which is very attractive to someone with low self-esteem. Other relevant facts are the size of the family and the existence of criminals in the family environment. The main crimes committed by women are theft, bodily injury, murder and drug trafficking. The latter being the most common, representing $45 \%$ of female prison populations (Da Paixão et al,2014).

Female involvement in drug trafficking is often due to the influence of men with whom they relate or with whom they have some kinship. This initiation can also occur independently, for financial reasons. High female unemployment, along with their low salary - when compared to males - contribute to more women seeking illicit activities to supplement income (Fraga e Silva, 2017).

Most of the women involved in trafficking are single mothers, unemployed or working informal jobs. Almost all did not receive the aid-seclusion. The insertion of women in trafficking is another form of sexual division of labor, because it allows women to reconcile crime with typically feminine obligations, such as caring for children and performing household activities (Martins, 2020).

The insertion of women in this mostly male environment grants them a prestige and power over other women. Carrying guns, causing fear and subjugating others, female traffickers experience a typically masculine power, and apply this power to women they consider weakest and most vulnerable (Barcinski and Cúnico,2016).

In an article published by "Veja" magazine in 2012, an increase of $402 \%$ of women arrested for crimes against property, including theft, extortion and swindle, was reported. This compared with a $97 \%$ increase in male prisoners for crimes in the same period. Women are increasingly entering the world of crime by choice, as they see it as a profitable or even fun alternative. Women have the surprise factor in their favor, as few distrust them. Men take longer to realize that they are targets of scams or robberies when committed by women (Jakitas, 2012).

With regard to violent crimes, such as physical aggression and, more specifically, homicide, women are often seen as passive subjects. An essentialist view of the phenomenon tends to place the woman murderer or in a position of victim, committing her crime because of the patriarchal oppression she suffered, or like crazy, suffering some kind of mental or emotional disorder that makes them act differently than expected. According to Ratton and Galvão (2016) the essentialist view makes women become "puppets of dimensions they do not control" (p.10) and disconsiders any volition, rationality and intention on the part of the authors (Ratton and Galvão, 2016).

Women are not seen as capable of committing crimes on purpose. They are seen as capable only of committing reactive homicides, which are by legitimate defense, by an explosion of love or some emotional imbalance or moment of hysteria. But that's not the case. Although, historically, men have shed more blood, there are psychopathic women who commit intentional homicides and even become serialkillers. It's believed that there were more than a thousand female serial killers - intelligent, grumpy, conniving women, seductors, reckless, selfish, delusional, willing to do what was necessary - but society seems to suffer from "collective amnesia" when it comes to female violence (Telfer, 2019).

In the book "Women who kill", the author Rosemary de Oliveira Almeida divides the murderous woman into three categories, according to her victims. The first category is the woman who kills her partner, who is usually starring women in domestic situations and is perceived as typically feminine. Women who commit this crime usually act in self-defense, because they suffer re-incident abuse from their partners and believe they have no other way to solve the problem, or act out of jealousy. The second category is that of the woman who kills enemies. In this crime, greater intentionality and rationality is perceived, the motivation is usually revenge and the victim can be a neighbor or co-worker (anyone, in fact). This crime is generally not committed alone, but with the presence of some accomplice. The last category is women who kill children. These are the most shocking cases, as there could be no legitimate defense or revenge as a motivator. Infanticide is a crime also considered typical of women and can occur not only intentionally, but due to negligence and mistreatment that can end in death (Almeida, 2001). 
There is a predominance of female aggressors in crimes against children. Not only infanticide, but neglects, mistreatment, psychological abuse, among others. Mothers are the most common aggressors, which is - possibly explained by the fact that they are physically closer to their children. In case of separation, for example, mothers are the ones who usually take custody (Nunes e Sales, 2016).

Even when there is no separation, the role of caring for children is still - typically - delegated to women and, consequently, there is a longer period of contact between them and the children. Paradoxically, mothers are also the ones who most protect children (Pierantoni and Cabral, 2009).

A crime that has become more common with the dissolution of the traditional family view and with the consequent increase in divorce numbers is parental alienation. Also known as AP, it consists of inducing a child to stand on the side of one of the parents and reject the other. It is a serious crime that can have serious consequences on the child's psychological development. Mothers are the ones who commit this crime the most and those who are least stigmatized for doing so. As a rule, the custody of children usually goes to mother and - therefore - she has more opportunity to influence the offspring (Garcia et al,2020).

Another typically female crime that has become more common is that of slanderous denunciation. This occurs when a woman, driven by anger or hurt, decides to take revenge by seeking out a police authority and making a false report of abuse against a man. Due to Law 11,340 of 2006 known as the Maria da Penha Law - any denunciation made at the police station is sufficient for the initiation of a police inquiry. This act is a doubly serious crime because - in addition to violating many of the accused's rights - it causes the state machine to move resources to protect the false accuser, resources that should be dedicated to protecting real victims of abuse (Proton, 2018).

\section{Conclusions}

The participation of women in criminal life is ancient, going back even before Christ. They are capable of performing such cruel or - even - worse acts than their male counterparts. Examples are Parysatis (a Persian noblewoman in the 5th century) and Annulles (sovereign of Sri Lanka in the 4th century) who used poisons to get rid of people who were "inconvenient" (Telfer,2019).

Nevertheless, the theme of female crime has always been set aside, because there has always been a belief in the inferiority of women, even in crime. In antiquity, women were not responsible for their crimes, and their close male relatives paid for female offenses. To this day, the subject is neglected, with few studies to debate about it (Alves, 2017).

Until recently, the study of women in crime was seen in comparison to the study of male crimes. This created a gap in the field of criminology (De Amorim and Cotrim, 2015).

The present study sought to address this theme that has not been explored, and found that female crime is marginalized and invisible. The woman is still seen as docile, a victim unable to commit crimes except when moved by strong emotions. The study also found the falsehood of this view, typifying crimes in which women are protagonists.

Finally, the article does not close the theme. That was not its intention and would not be an achievable goal. It intends to add to the debate and generate reflections about female crime, in the hope that multiple other studies will fill the lacunas still existing.

\section{Acknowledgments}

We would like to thank the University Center of Vitória de Santo Antão (UNIVISA) and professors Pierre Teodosio Félix and Maria Ubiracelma Carneiro da Cunha.

\section{References}

[1] ALMEIDA, R. O. Mulheres que matam: universo imaginário do crime no feminino. Rio de Janeiro: Relume Dumará: UFRJ, Núcleo de Antropologia da Política, 2001;

[2] ALVES, J. S. A. Criminalidade feminina: um estudo descritivo dos dados estatísticos acerca das mulheres detidas no Brasil e na Argentina. Revista Direito Humanos e Democracia. v. 5, n. 10, p. 175-212 (2017);

[3] BARCINSKI, M.; CÚNICO, S. D. Mulheres no tráfico de drogas: retratos da vitimização e do protagonismo feminino. Civitas, Porto Alegre, v. 16, n. 1, p. 59-70. (2016);

[4] DA PAIXÃO, A.G.; PAIXÃO, H. N. C.; SANTOS, J. P.; DOS SANTOS, K. K. M. Criminalidade feminina: a motivação na transgressão da lei. Raizes do Direito, n. 3, p. 115-134 (2014);

[5] DE AMORIM, B. R. C.; COTRIM, G. S. A criminologia e o debate feminista: mulheres como autoras de crimes. VII Jornada Internacional de Políticas Públicas. Maranhão (2015);

[6] FARIA, T. D. A mulher e a criminologia: pelações e paralelos entre a história da criminologia e a história da mulher no Brasil. Fortaleza - CE - junho de 2010;

[7] FRAGA, P. C. P.; SILVA, J. K. N. A participação feminina em mercados ilícitos de drogas no Vale do São Francisco, no Nordeste brasileiro. Tempo Social, revista de sociologia da USP, v. 29, n. 2, p. 135-158 (2017);

[8] GARCIA, C. C. H.; CARDOSO, N. O.; MODESTI, S. R. $\mathrm{S}$. Os sentimentos e os traços de personalidade de pais alienadores: uma revisão integrativa. Psicologia desde el Caribe. v. 37, n. 2, p. 88-110 (2020);

[9] GERMANO, I. M. P.; MONTEIRO, R. A. F. G.; LIBERATO, M. T. C. Criminologia Crítica, Feminismo e Interseccionalidade na Abordagem do Aumento do Encarceramento Feminino. Psicologia: Ciência e Profissão, Vol. 38, Ed. 2 (2018);

[10] JAKITAS, R.; Roubos e furtos praticados por mulheres crescem 400\%. Veja, 2012. Disponível em: $<$ https:/veja.abril.com.br/brasil/roubos-e-furtos- 
praticados-por-mulheres-crescem-400/>. Acesso em: 20/10/2021;

[11] LOMBROSO, C.; FERRERO, G. A mulher delinquente: a prostituta e a mulher normal. Curitiba: Antonio Fontoura, 2017;

[12] MAGNO, V. P. M. Mulheres que Matam: o crime de homicídio praticado por mulheres em Belém-Pará. Dissertação (Pós-Graduação em Segurança Pública) Instituto de Filosofia e Ciências Humanas, Universidade Federal do Pará. Belém, p. 95 (2019);

[13] MARTINS, C. B. Trabalho invisível e ilícito: reflexões criminológicas críticas e feministas do aumento do encarceramento de mulheres por tráfico de drogas no Brasil. Rev. Direito e Práx., Rio de Janeiro, v. 11, n. 4, p. 2635-2668 (2020);

[14] NUNES, A. J.; SALES, M. C. V. Violência contra crianças no cenário brasileiro. Ciência \& Saúde Coletiva. vol. 21, ed. 3, p. 871-880 (2014);

[15] PIERANTONI, L. M. M.; CABRAL, I. E. Crianças em situação de violência de um ambulatório do Rio de Janeiro: conhecendo o seu perfil. Escola Anna Nery vol. 13 ed. 4 (2009);

[16] PRÓTON, S. Belas e feras: a violência doméstica da mulher contra o homem. Belo Horizonte: Manduruvá Edições Especiais, 2018;

[17] RATTON, J. L.; GALVÃO, C. Para além da maldade, da loucura e da vitimização: Agência intencional e volição em crimes violentos praticados por mulheres. Civitas, Porto Alegre, vol. 16, n. 1 (2016);

[18] SALMASSO, R. C. Criminalidade e condição feminina: estudo de caso das mulheres criminosas e presidiárias de Marília-SP. Revista de Iniciação Científica da FFC, v. 4, n. 3, p. 16-31 (2004);

[19] STARR, S. B. Estimando disparidades de gênero em processos criminais federais. Escola de Direito da Universidade de Michigan, n. 12-018, p. 41, 2012. Disponível em: $<$ https://papers.ssrn.com/sol3/papers.cfm?abstract_id=2 144002 >. Acesso em: 20/10/2021;

[20] TELFER, T. Lady killers: assassinas em série. Rio de Janeiro: Darkside books, 2019; 